\title{
BODY BECOMING IMAGE: THE THEATRICAL WINDOW
}

\section{CLAUDIO ROZZONI}

$\mathrm{PhD}$ in «Aesthetics and Theory of Art» from the University of Palermo, a FCT post-doc fellow at the Nova Institute of Philosophy (IFILNOVA), New University of Lisbon, 1069-061 Lisbon, Portugal.

E-mail: claudio.rozzoni@gmail.com

This paper aims to analyze the question of how to define the essence of the theater, building on a conference Spanish philosopher Ortega y Gasset held in Lisbon in April 1946, where he radically raised the question of the «strange» relationship between reality and unreality that the «world of the stage» makes possible for us to experience. On the one hand, Ortega states that theater is essentially vision, while, on the other hand, it seems that such a seeing, in itself, leads to a problematic relationship with a not-seeing. In particular, Ortega seems to claim that in theater spectators experience a vision both «paradoxical» and «magic», insofar as it entails an essential not-seeing that gives rise to a play between opacity and transparency. A play that is also to be found in a masterwork many phenomenologists admired, Proust's Recherche, in which, in order for Marcel to see the image of Phaedra, the ordinary body of the actress Berma has to vanish. Here the body becomes transparent and one no longer sees the performer himself: he/she is simply a window opening upon a great work of art. This way, the spectator can experience «this new order of creatures» that reminds us of the «êtres d'une nouvelle nature» of which Du Bos wrote in the Eighteenth Century. However, regarding the topics of the «image-window», Eugen Fink and his teacher Edmund Husserl had already paved the way, and an intertwined reading of some important texts of both authors can in turn shed new light on this question. With regard to Husserl, special attention will be paid to a very interesting text from the Husserliana XXIII (probably dating to 1918) in which he, taking theatrical image into profound consideration, draws attention to the both paradoxical and powerful notion of perceptual phantasy.

Key words: aesthetics, image, theater, transparency, opacity, window, perceptual phantasy, feelings.

\section{ТЕЛО СТАНОВИТСЯ ОБРАЗОМ: ТЕАТРАЛЬНОЕ ОКНО}

\section{КЛАУДИО РОЦЦОНИ}

$\mathrm{PhD}$ в области «Эстетики и теории искусства» Университета Палермо, пост-докторант в Nova Institute of Philosophy (IFILNOVA), Новый университет Лиссабона, 1069-061 Лиссабон, Португалия.

E-mail: claudio.rozzoni@gmail.com

(C) Claudio Rozzoni 
В этой статье автор стремится проанализировать проблему определения сущности театра, опираясь на доклад испанского философа Ортеги-и-Гассета, прочитанный в Лиссабоне в 1946 году, в котором он радикальным образом поставил вопрос о «странном» отношении между реальностью и нереальным, которое мы можем пережить благодаря «сценическому миру». С одной стороны, Ортега утверждает, что театр по сути визуален, хотя, с другой стороны, кажется, что это видение само по себе приводит нас к проблематичному взаимодействию с не-видением. В частности, создается впечатление, что согласно Ортеге, театральный зрители обладают одновременно «парадоксальным» и «магическим» опытом видения, поскольку оно сущностным образом включает в себя не-видение, из которого берет начало игра между прозрачностью и непроницаемостью. Игру такого рода можно также найти в блестящем произведении, привлекавшем многих феноменологов, а именно в цикле «В поисках утраченного времени» Пруста, в котором, чтобы Марсель мог увидеть образ Федры, повседневное тело актрисы Берма должно исчезнуть. Здесь игра становится прозрачной и мы больше не видим самого исполнителя: он/она - это только окно, открывающееся на значимое произведение искусства. Таким образом, зритель может пережить «новый порядок творений», который напоминает нам описанный Дю Босом в восемнадцатом веке «новый порядок творений (êtres d'une nouvelle nature)». Однако тема «образа-окна» была значительным образом разработана Ойгеном Финком и его учителем Эдмундом Гуссерлем, и перекрестное чтение ключевых текстов обоих авторов может пролить новый свет на этот вопрос. Что касается Гуссерля, то мы будет особенно тщательно разбирать исключительно интересный текст из Husserliana XXIII (вероятно 1918 года), в котором он, подвергая глубокому разбору театральный образ, обращает внимание на одновременно парадоксальное и значимое понятие периептивной фантазии.

Ключевые слова: эстетика, образ, театр, прозрачность, непроницаемость, окно, перцептивная фантазия, чувства.

\section{Proustian Window}

Lisbon, April 13, 1946. The Spanish philosopher Ortega y Gasset holds an important conference. $O$ Século had invited him to inaugurate a series of conferences dedicated to the history of theater with one supposed to explain what theater is. "What is theater?» (Ortega y Gasset, 1975, 163): that is a Socratic question which brings us directly to the question of the Idea of theater. Through his phenomenological approach, Ortega characterizes theater - and he does that considering the prestigious example of the theater Dona Maria of Lisbon — as essentially constituting a «duality», in which we can distinguish three levels of couplets, namely the «spatial» couplet stage/theater hall, the «human» (Ortega y Gasset, 1975, 173) couplet spectator/actor and also a duality regarding the direction of vision: there it seems to be a threshold between those who see, the audience, and those who are seen, the actors. ${ }^{1}$ As we shall observe, this is not a split, at least in the current meaning of the word. Rather, what seems to change between the two parts in question is the quality of the air, because on the «stage» the «atmosphere» is «less dense <.. > than that of the hall» (Ortega y Gasset, 1975, 184).

1 See (Ortega y Gasset, 1975, 173-174). 
Along these lines, Ortega states that theater is essentially vision. The Greek word theatron, from which, as it is well known, theater stems, already seems to reveal what is at the heart of the matter in this art. Yet, it seems that such a seeing, in itself, leads to a problematic relationship with a not-seeing. From the very beginning, we can foresee that vision in theater is not ordinary vision - at least in two senses. On the one hand, in theater vision is something more than ordinary vision, but, on the other hand, one can affirm that in theater we see less than we do in everyday life. What kind of vision happens at the threshold between spectator and actor?

Ortega regarded Proust's masterpiece $\dot{A}$ la recherche $d u$ temps perd $u$ very highly. In this work, which Heidegger and Husserl also admired (and qualified as phenomenological), ${ }^{2}$ we can find a very rich description of the experience of being a spectator. More precisely, we find an important contribution to the issue we raised about the vision of the spectator, about what the spectator sees. The Narrator of the Recherche, let us call him Marcel, experiences the way in which his eyes see the actor's body, and the fact that the actor's body appears through a play between opacity and transparency. In order for Marcel to see Phaedra on the stage, for example, the body of the actress Berma, in a certain sense, has to disappear. Better said: in order for Marcel to see the image of Phaedra, the ordinary body of the actress Berma has to vanish. The gestures of the actress are, as Deleuze pointed out in his work on Proust, sine materia «inert» and «refractory to spirit» (Deleuze, 2000, 40), ${ }^{3}$ and they «form a transparent body that refracts an essence, an Idea» (Deleuze, 2000, 39, italics added). Yet the notion of transparency, when we talk about a «transparent body», can once more mislead us. Rather, it would be more fruitful both to draw attention to the "productive» power of the matter and to underline the ability to shine that it has when it does not shy away from the «Idea», the «Essence». ${ }^{4}$ Thus, according to Deleuze, Proust's analysis shows us that great actors become images when they are able to make their body shine with the essence. On the contrary, poor actors cannot get rid of their own ordinary body. So, at this point, one thing that must be asked is which kind of matters, from the point of view of art, would be «refractory to spirit». If we stay in the context opened up by Berma's acting, we can thus say that such matters can be the tears of the «mediocre actresses» (Deleuze, 2000, 39) siding with Berma on the stage in the Phaedra. For example, they have to point out to the audience that what they are acting out is sad, and in doing that they have to resort to tears. In turn, in such cases, the member of the audience who wants

2 See for example what François Vezin says, interviewed by Agathe Malet-Buisson (Vezin, 2000, 104) and also what Malvine Husserl says in the letter to Heidegger she wrote with her husband (Husserl, E., Husserl, M., 1994, 144): «Dear Heidegger < ..> read Curtiu's essay on Proust, absolutely phenomenological and very interesting».

3 See (Proust, 1983b, 44).

${ }^{4}$ «Essences or Ideas, that is what each sign of the little phrase reveals [scil: Vinteuil's little musical phrase]» (Deleuze, 2000, 40). 
to offer a sign of the fact that he/she is understanding the actors' performance will show, at the bursting of the tears, a pained expression. To put it briefly, in the acting of the «mediocre actresses», we can detect «intentions» (Proust, 1986, 44). Instead, contrary to what we have seen happening to the «mediocre actresses», in Berma's acting intentions do not «stick out» $\rangle^{5}$ of the role. Her body has become image, a sensible image allowing spectators to experience an essence. As Proust also says - and in doing so he compares actor and pianist, Berma and another great artist character in the Recherche, that is to say the pianist and composer Vinteuil - the «playing has become so transparent, so imbued with what» he/she «is interpreting, that one no longer sees the performer himself — he is simply a window (fenêtre) opening upon a great work of art» (Proust, 1983b, 44).

\section{Magic and play}

Along these lines, what kind of images are those we see on the stage? Do we see images or bodies? And, in the first case, how «truthful» are these images? One could say either that theatrical images are dangerous and unreliable representations, that is notably the way of thinking pointed out by Rousseau, or, perhaps, based Du Bos' suggestions, ${ }^{6}$ and Proust's, on the other hand, one could claim they are «creatures» of a «new order» (Proust, 1983a, 92). Let us proceed with order. If we return to Ortega's Lisbon Conference where we started, we find that according to the Spanish philosopher as well the discriminating way to discern good actors from poor ones is intimately related to this «play» between opacity and transparency. He asks if that «pale fiammetta» we see on stage is Ophelia or rather is Marianinha Rey Colaço. Once again it seems «we see double», and we have been thrown in front of a dilemma: we do not truly know what we are actually seeing in this case. Indeed, on the one hand, this would seem to be the case of an «optical illusion» (Ortega y Gasset, 1975, 176), yet, on the other hand, we are involved in a «magical» process that gives us access to a different «reality»:

Is it not strange, extraordinary, literally magical, that a man and woman of Lisbon can sit today, in 1946, in the box and orchestra seats of the Dona Maria Theater and at the same time be there six or seven hundred years ago in foggy Denmark $\langle\ldots$. , and there see this pale fiammetta, Ophelia, walking along with her airy step? If this isn't extraordinary and magical, I know of nothing in the world closer to being so! (Ortega y Gasset, 1975, 177).

Actually, Ortega argues, we do not see Marianinha «because she is hidden by Ophelia», just as «the stage sets are hidden, covered by a park and a river» (Ortega y Gasset,

\footnotetext{
5 See (Proust, 1983b, 44).

${ }^{6}$ «L'art ne pourroit-il pas créer, pour ainsi dire, des êtres d'une nouvelle nature?» (Du Bos, 1770, 26).
} 
1975, 177). Likewise, in Proust's Search Marcel has to not see the actress Berma in order to see Phaedra. And this actress is a great one insofar as she is able to conceal herself. Thus, it is interesting to note that according to the German phenomenologist Eugen Fink — whom Ortega personally met when he visited Husserl in Freiburg in 1934 —, the image consciousness (Bildbewusstsein) essentially entails in itself a ""not seeing" (Übersehen)» (Fink 1966, 74) (I refer here to the Dissertation he defended in 1929 and for which «Husserl stood as Referent and Heidegger as Korreferent» (Bruzina, 2004, 18)). In order for one to see the «image world (Bildwelt)» (Fink, 1966, 74), Fink states, something has to be «not seen». And, even more interestingly, [he states] that the image world has its own time and its own space, which are, once again, different from those belonging to reality. As Fink pointed out, objects in the image world «are not objects in real space and they do not last in real time» (Fink, 1966, 75). So, the image seems to be «unreal». Nevertheless, to be more precise, in a sentence that might sound like a pun, «the unreality of image is» characterized as «a real "appearance" (Schein)» (Fink, 1966, 76, italics added). From here, it is a short step, through Fink, to rejoin the Proustian claim we recalled above. In this particular way Fink is able to state that the image can be thought of as a «window» opening upon an «image world» (Fink, 1966, 77). ${ }^{8}$ This does not mean that the image world is a transcendent one. Here «image world» stands for anything but a world shining in the image. Theater, in particular, does not conjure images that stand for something absent: theater presents its images originally, it presents them through sensibility. So, a little stage can allow us to see a universe, just like in a little painting, Ortega remarks, «we see a landscape several miles across» (Ortega y Gasset, 1975, 178).

From this point of view Fink's teacher, Edmund Husserl, had already paved the way, and in general, an intertwined reading of some important texts of both authors can in turn shed new light on the topics of the image-window and on the play between opacity and transparency that images allow us to experience. As far as the father of phenomenology is concerned, I would like to call attention to a very interesting text from the Husserliana XXIII (probably dating to 1918) ${ }^{9}$ in which Husserl takes into profound consideration theatrical image, and, specifically, what I wish to draw attention to here is the notion of perceptual phantasy. As in the two cases we have already introduced, that is to say, Marianinha/Ophelia and Berma/Phaedra, Husserl emphasizes that in the «theatrical performance» (Husserl, 2005, 612) «the king on the stage is indeed an actual human being with actual garments - except that in reality, of course, the king is Herr actor so-andso and not king, his robe is a part of the theatrical wardrobe and not a coronation robe,

\footnotetext{
7 See (Husserl, 1968, 90).

8 Even though it remains to be seen how these windows are meant to function in both cases. Is a window opening upon an «image world» the same as a window «opening upon a work of art»? Opening upon an image world is not yet opening upon a work of art (at least in the Proustian sense mentioned here).

9 See Husserl E. «On the Theory of Intuitions and Their Modes (texts probably from 1918)» (Husserl, 2005, 599-625).
} 
and so on» (Husserl, 2005, 611, italics added). Now, according to the phenomenological spirit, «one must restrict oneself to the phenomena themselves» so that one can actually identify on the stage a form of «conflict», the one in virtue of which «the picture on the wall gives a perceptual (perzeptives) figment, as if I were looking through a window» (Husserl, 2005, 611-612). ${ }^{10}$ It can also be said — following Husserl as well as his pupil Fink — «that reality changes into reality-as-if for us, changes into "play" (Spiel)» (Husserl, 2005, 615). In the air of the theater - recalling Ortega's reference to the peculiar air of the stage - we see «from the beginning» in the as-if, «we do not begin with the thesis of the reality of what appears perceptually» (Husserl, 2005, 617-618). The most important aspect of such Husserlian remarks on theater, however, is the peculiar formulation of the notion of image. All the more that on this topic the pages from 1918 seem to represent a significant change of heart in his thought: «Earlier I believed that it belonged to the essence of fine art to present in an image, and I understood this presenting to be depicting (Abbilden). Looked at more closely, however, this is not correct» (Husserl, 2005, 616). And precisely here Husserl chooses to refer to theater: «in the case of a theatrical performance», he says, «we live in a world of perceptual phantasy [perzeptive Phantasie]», "we have "images" (Bilder) < .. > but we do not for that reason have depictions (Abbilder)» (Husserl, 2005, 616). ${ }^{11}$ Poor actors make an effort to signify something external to them. Good actors, instead, are able to «produce $<\ldots>$ an image of a character in the play» (Husserl, 2005, 616) as Berma produces an image of Phaedra. «But here», again, «"image of” ("Bild von”) does not signify depiction of (Abbild von)» (Husserl, $2005,616)$. To put it more clearly: «when a play is presented», «we live in neutrality (Neutralität)» and no «positing» at all needs to be «carried out» (Husserl, 2005, 617). The moment we say that the body on stage is Marianinha, we are establishing a positing, but we are losing an image: that of Ophelia. Now, one step is still missing.

\section{Reality and unreality}

If it can be said, along with Husserl, that «the actors, the real things called "scene" serve to transplant us into the artistic illusion», then it is also necessary to say that this

\footnotetext{
${ }^{10}$ And again, if we do have a window, it remains to be seen what precisely it is opening upon and what it allows us to experience through perceptual (perzeptive) phantasy.

${ }^{11}$ "Wir haben "Bilder", < ..> aber darum nicht Abbilder». It is important to note that «perceptual» here stands for «perzeptiv» and not for «Wahrnehmungs...». So what we are dealing with here is a «pure positionless perception (Perzeption)», to some extent a «perception» that, contrary to Wahrnehmung, does not hold [nehmen] anything as true (wahr): «Husserl sometimes uses Wahrnehmung and its derivatives in contrast to Perzeption and its derivatives to indicate the difference between ordinary perceptual experience with its belief in empirical reality (Wahrnehmung) and the unique kind of perception involved in the experience of an image (Perzeption)» (Husserl, 2005, 556, translator's note).
} 
illusion is not to be understood in «the ordinary sense, $<\ldots>$ as a "semblance" to which we "succumb"» (Husserl, 2005, 617). As Ortega also will, ${ }^{12}$ Husserl points out the fact that «we "know" that what is happening» on the stage «is play acting, that these pasteboard scenes and canvas screens are not actual trees, and so on. In a certain inactive (passive) manner, everything that is "seen" here has the characteristic of what is null, of what is cancelled, or, better, of what is annulled with respect to its reality» (Husserl, 2005, 618, italics added). In 1968, in a conference concerning the relationship between theater and play (Spiel), entitled Maske und Kothurn, even though in his own way, Fink recalled Husserl's lesson drawing on the notion of window ${ }^{13}$ looking out upon a world, which had already had a major role in his 1929 Dissertation. Such a world that is built by theater through that window called scene is not a merely subjective world. Rather "the play», like the «novel» — as Husserl previously stated — «has intersubjective "existence"» and therefore «judgments about the characters $<\ldots>$ have a kind of objective truth, even though they refer to fictions» (Husserl, 2005, 621). For both Proust and Husserl, novel and theater have that in common, that they can edify a world through image. ${ }^{14}$

Still, it remains to be seen which relationship subsists between the world of image and the real world. ${ }^{15}$ According to Husserl, «reality and phantasy can be separated, but also can mingle» (Husserl, 1959, 113). Here Proust seems to suggest something more, however. In order to show what, I want to focus on a Proustian passage in which the discussion about the world of the novel emerges. Horse sense, like Françoise (Marcel's family governess in the Recherche), could say «that the people concerned» in the world of the novel are not «"real people"» (Proust, 1983a, 91). Nevertheless, the Narrator makes a decisive remark when he points out how «none of the feelings which the joys or misfortunes of a «real» person arouse in us can be awakened except through an image

12 «The river was not a river, but paint; the trees were not trees, but daubs of color. Ophelia was not Ophelia, she was... "Marianinha" Rey Colaço!» (Ortega y Gasset, 1975, 176).

${ }^{13}$ See (Fink 1971, 14).

${ }^{14}$ Of course, we are not saying that the Husserlian (as well as the Finkian) window and the Proustian window allow us to see the same objects, the same quality of world. At this point we should begin developing another level of the discussion in order to show which points of each way of thinking also belong to the other and which do not. If the two windows «force» us to experience an objective world, when could we say that they «force» us to experience a «great work of art», as in the case of Proust we cited above? Here it must be added that if on the one hand the «ordinary Berma» disappears in order to let Marcel see Phaedra, on the other hand the essence of Phaedra appears with Berma's accent, and in the name of her style, Phaedra becomes «the masterpieces» of the actress: «Thus into the prose sentences of the modern playwright as into the verse of Racine Berma contrived to introduce those vast images of grief, nobility, passion, which were the masterpieces of her own personal art, and in which she could be recognised as, in the portraits which he has made of different sitters, we recognise a painter» (Proust, 1983b, 48).

${ }^{15}$ With the knowledge that this last issue is intimately related to what we have discussed up to now concerning the «quality» of the experience the image window makes possible. 
of those joys or misfortunes» (Proust, 1983a, 91, italics added, translation modified). This statement is quite impressive, especially after having qualified the actor's body as image. In this passage, Proust does claim that in order for us to feel either joy or sorrow for someone we need not only the body of «flesh and blood» of the person in question, but also his or her image. Perhaps then not only can it be said along with Fink that the images theater produces see us back - and as a result that theater is essentially vision in two ways (not only spectator toward actor but also actor toward spectator) - but also that theater shows us how we can have feelings for others. It is as though image were the transcendental aspect of feeling, as though it were its condition of possibility. If one accepts these premises, then one can also say, along with the Narrator of the Recherche, that «the ingenuity of the first novelist» - clearly a «mythical character» of that great theater put on by the Proustian Recherche - «lay in his understanding that, as the image was the one essential element in the complicated structure of our emotions, so that simplification of it which consisted in the suppression, pure and simple, of "real" people would be a decided improvement» (Proust, 1983a, 91, italics added).

Therefore, to accomplish such an improvement, would that be the same as removing the concrete reality of those «real characters» that people are, in order to let us see the «image character» which lives in them? In the linguistic world of the novel, Proust suggests, such a «suppression» is perhaps more natural to realize than we are allowed to experience in our everyday life:

A «real» person, profoundly as we may sympathise with him, is in a great measure perceptible only through our senses, that is to say, remains opaque, presents a dead weight which our sensibilities have not the strength to lift. <...> The novelist's happy discovery was to think of substituting for those opaque sections, impenetrable to the human soul, their equivalent in immaterial sections, things, that is, which one's soul can assimilate (Proust, 1983a, 91, italics added).

For the actor, instead, achieving this «dematerialization» seems to be a more problematic endeavor: how to make the body disappear, to make it transparent, in order to let us see the image, in order to let it be an image, how to make the actor's body a «window» «opening upon the work of art», as we heard Proust say. For the actor, the play, in this case, consists in overcoming the opacity of the real character's body in order to render the «immaterial sections», "which the soul can» more easily «assimilate», fully sensible. This way the spectator can experience «this new order of creatures» (Proust, 1983a, 92) that reminds us of the «êtres d'une nouvelle nature» of which Du Bos wrote in the Eighteenth Century.

According to Proust, the novelist and the actor must be able to dematerialize their body, aiming not to annul it, but rather to make the body shine in a new light, that of the essence. They want to remove from the body, as it were, that ordinary and mere sensible opacity that makes it more difficult for us to experience the «incorporeal events» 
(Deleuze, 1990, 132) that, Deleuze would say, «insist» (Deleuze, 1990, 53) in «what happens» (see Deleuze, 1990, 149-153) - physically locatable - everyday. There exists a strict correlation between «real» image in real life and «unreal» image on stage. Perhaps even in reality, every time we have feelings, as Proust says, we never have the mere body in itself. ${ }^{16}$ And the «real» and «unreal» image are related insofar as they share the invisible truth of essence, that is to say their common source. Hence, since it is possible for the Proustian spectator to experience the incorporeal event at the surface of the actor's gesture (when the actor does not allow any muscle to stick out of the essence he shows), the Proustian theater with its own peculiar paradoxes can thus be understood, like the Diderotian theater, as a theater of knowledge, where impersonal lives - having to do with joys and idiosyncrasies bigger than those we experience in our personal lives - give life to an ideal spectacle where the matter shines - as Deleuze would put it — with the «splendor of the event» (Deleuze, 1990, 152), ${ }^{17}$ of that essence which is «ordinarily $<\ldots>$ invisible» (Proust, 1983c, 1103) ${ }^{18}$ in our daily lives.

\section{REFERENCES}

Bruzina, R. (2004). Edmund Husserl \& Eugen Fink: Beginnings and Ends in Phenomenology, 1928-1938. New Haven \& London: Yale University Press.

Deleuze, G. (1990). The Logic of Sense. New York: Columbia University Press.

Deleuze, G. (2000). Proust \& Signs. The Complete Text. Minneapolis: University of Minnesota Press.

Du Bos, J.-B. (1770). Réflexions critiques sur la poésie et sur la peinture. Paris: Pissot.

Fink, E. (1966). Vergegenwärtigung und Bild. Beiträge zur Phänomenologie der Unwirklichkeit. In Studien zur Phänomenologie, 1930-1939 (1-18). Den Haag: Nijhoff.

\footnotetext{
${ }^{16}$ And from this point of view it would be interesting to develop the relationship between mere reality and played reality also starting from a Wittgensteinian approach. On this matter, see (Molder, 2010, 39-63). In particular, «in principle, if we dropped this image we should have the fact, which stands behind it. But this is evident that dropping the image leaves us with no fact at all. Behind the image lies nothing» and so one could say images «are but false substitutes» (Molder, 2010, 47). It is not by chance, then, that «in [Wittgenstein's] last texts, facts $\langle\ldots\rangle$ are $\langle\ldots\rangle$ seen as $\langle\ldots\rangle$ variations of forms of life» and they «are named $<\ldots>$ games, Spiele» (Molder, 2010, 50).

${ }^{17}$ «The actor» in Logic of Sense «belongs to the Aion. < ..> The actor or actress represents, but what he or she represents is always still in the future and already in the past $\langle\ldots\rangle$. It is in this sense that there is an actor's paradox: the actor maintains himself in the instant in order to act out something perpetually anticipated and delayed, hoped for and recalled» (Deleuze, 1990, 150).

${ }^{18}$ «That form < .. > which ordinarily, throughout our lives, is invisible to us: the form of Time» (Proust, 1983c, 1103).
} 
Fink, E. (1971). Maske und Kothurn. In Epiloge zur Dichtung (1-18). Frankfurt am Main: Klostermann.

Husserl, E. (1959). Erste Philosophie (1923/1924). Zweiter Teil: Theorie der phänomenologischen Reduktion (Hua VIII). Den Haag: Nijhoff.

Husserl, E. (1968). Briefe an Roman Ingarden. Mit Erläuterungen und Erinnerungen an Husserl. Den Haag: Nijhoff.

Husserl, E. (2005). Phantasy, Image Consciousness and Memory (1898-1925). Dordrecht: Springer.

Husserl, E., \& Husserl, M. (1994). E. und M. Husserl an Heidegger, 26. V. 1927. In E. Husserl, Husserliana Dokumente, Band III. Briefwechsel, Teil IV. Die Freiburger Schüler. Dordrecht, Boston, London: Kluwer Academic Publishers.

Molder, M. F. (2010). Cries, False Substitutes and Expressions of Life. In A. Marques \& N. Venturinha (Eds.), Wittgenstein on Forms of Life and the Nature of Experience (39-64). Bern: Peter Lang.

Ortega y Gasset, J. (1975). The Idea of Theater. An Abbreviated View. In Phenomenology and Art (163-195). New York: W.W. Norton \& Company.

Proust, M. (1983a). Swann's Way. Remembrance of Things Past (Vol. 1). London: Penguin Books.

Proust, M. (1983b). The Guermantes Way. Remembrance of Things Past (Vol. 2). London: Penguin Books.

Proust, M. (1983c). Time Regained. Remembrance of Things Past (Vol. 3). London: Penguin Books.

Vezin, F. (2000). Du côté de Husserl et Heidegger. Le Magazine littéraire, 2 (4), 104-107. Hors-Série. 